\title{
An International Survey of the Evidence on the Pecking Order Theory of Corporate Financing
}

\author{
Chikashi Tsuji \\ Graduate School of Systems and Information Engineering, University of Tsukuba \\ 1-1-1 Tennodai, Tsukuba, Ibaraki 305-8573, Japan \\ E-mail: mail_sec_low@minos.ocn.ne.jp
}

Received: August 25, 2011 Accepted: September 11, 2011 doi:10.5296/ber.v1i1.952

\begin{abstract}
Despite theoretical continuing developments in many past years, our understanding of the relationship between theories and practical corporate financing decisions remains incomplete. Therefore, this paper aims to supply the comprehensive material for better understanding of the capital structure, in particular, of the pecking order theory of corporate financing. With this aim, more specifically, we first survey literature related to the pecking order theory to widely introduce the empirical evidence including not only for the US but also for other international countries. Furthermore, in order to introduce the literature that conducted survey research as well, we also survey the international practical situations of corporate financing decisions related to the pecking order theory.
\end{abstract}

Keywords: Asymmetric information, Capital structure, External financing, Pecking order theory. 


\section{Introduction}

A seminal paper of Myers (2003) documented that "Financing is half of the field of corporate finance (Myers (2003, pp.247))." In some theories and hypotheses of this important corporate financing in the research field of capital structure, the traditional pecking order theory is really important as many continuing arguments on this topic demonstrate. Some of the important traditional papers discussed this pecking order theory are for example, Myers (1984), Myers and Majluf (1984), Shyam-Sunder and Myers (1999), and Chirinko and Singha (2000).

As widely known, Myers has greatly contributed to the research field of capital structure. More concretely, as Allen et al. (2008) documented, after Modigliani and Miller's (MM's) classic theory, the second generation studies on capital structure focused on other real-world 'frictions', which were arisen from the costs and benefits of debt. Allen et al. (2008) explained that among the most important of these post-MM papers were three by Myers: (1) the first was Myers (1977), which set out the concept of debt overhang. This concept became a cornerstone of the static trade-off theory; (2) Second was Myers and Majluf (1984), which laid the foundations of the pecking order theory, and this theory continues to be the main rival to the static trade-off theory; and they thirdly listed the Myers' 1983 Presidential Address to the American Finance Association, which evaluated the claims of these two rival theories.

Considering the importance of the pecking order theory, this paper broadly surveys the related evidence documented in academic literature by focusing both on the US and international empirical results. Further, since our newest survey covers not only international empirical results but also survey evidence, this paper widely contributes to the international researchers and practitioners.

The reminder of this paper is organized as follows. Section 2 concisely introduces the pecking order theory of capital structure, Section 3 provides the literature review focusing on the evidence in the US, and Section 4 supplies the survey of the empirical results of international studies. Further, Section 5 describes the evidence from the survey research, and Section 6 concludes the paper.

\section{The Pecking Order Theory}

An important survey of Myers (2003, pp.235) documented the pecking order theory of corporate financing as following citations $((1)-(4))$.

(1) Firms prefer internal to external finance. (Information asymmetries are assumed relevant only for external financing.)

(2) Dividends are "sticky", so that dividend cuts are not used to finance capital expenditure, and changes in cash requirements are not soaked up in short-run dividend changes. Changes in free cash flow (operating cash flow less investment) show up as changes in external financing.

(3) If external funds are required for capital investment, firms will issue the safest security first, that is, debt before equity. As the requirement for external financing increase, the firm 
will work down the pecking order, from safe to riskier debt and finally to equity as a last resort, when the firm is sufficiently threatened by financial distress. If internally, generated cash flow exceeds capital investment, the firm works up the pecking order. Excess cash is used to pay down debt rather than repurchasing and retiring equity.

(4) The firm's debt ratio therefore reflects its cumulative requirement for external financing.

As stated, the pecking order theory was developed mainly by Myers (1984) and Myers and Majluf (1984), and after that, other studies such as Brennan and Kraus (1987), Noe (1988), Constantinides and Grundy (1989), Cadsby et al. (1990), Dybvig and Zender (1991), Persons (1994), and Cadsby et al. (1998) theoretically argued this theory further. Harris and Raviv (1991) provided an important literature review as to the theoretical developments of the overall capital structure issues. As other recent theoretical research related to the pecking order theory, such studies as Fulghieri and Lukin (2001), Garlappi and Huang (2006), Guriev and Kvasov (2009), Hennessy et al. (2010), Morellec and Schürhoff (2011), and Rocheteau (2011) exist.

\section{US Empirical Evidence}

This section introduces the literature that supplied the related evidence to the pecking order theory in the US. First, Lee and Gentry (1995) linked the overall financial health of a corporation, which was measured by a corporation's cash flow to the type of security it offers (straight bonds, convertible bonds or common stocks). They found that the cash flow components were useful in explaining the type of security offered, and they insisted that, consistent with the financial health/pecking order theory, their findings suggested that straight debt was chosen by financially healthy corporations, and stocks were offered by financially weaker corporations. Next, Shenoy and Koch (1996) focused on two theories of capital structure under asymmetric information, which insisted the contradict linkage between a firm's financial leverage and cash flow. Namely, the signaling theory suggests a positive linkage, while the pecking order theory implies a negative linkage. Their evidence for the US corporations revealed that, contemporaneously, leverage and cash flow tended to be negatively linked, while across time, leverage was positively related to future cash flow. Based on the evidence, they suggested that the apparent contradictions in the previous theoretical and empirical literature would be reconciled by considering both the contemporaneous and intertemporal aspects of the corporate leverage/cash flow linkage.

Further, Jung et al. (1996) investigated the ability of the pecking order model, the agency model, and the timing model to explain corporate decisions whether to issue debt or equity. They examined the stock price reactions to corporate decisions and their actions afterward. They insisted that their empirical evidence strongly supported for the agency model, while US corporations often departed from the pecking order because of agency considerations. They also reported that they could not find the supportive evidence in the US for the timing model. Helwege and Liang (1996) investigated the pecking order model of capital structure by examining the financing of US corporations that went public in 1983. Their results indicated that the probability of obtaining external funds was unrelated to the shortfall in internally generated funds, although corporations with cash surpluses avoided external 
financing. Finally, they concluded that US corporations that could access the capital markets did not follow the pecking order when selecting the type of security to offer.

Next, Fama and French (2002) reported that, from their empirical analysis, they identified one inconsistency regarding the trade-off theory (i.e., the negative linkage between leverage and profitability), one defect as to the pecking order theory (i.e., the large equity issues of small low-leverage growth corporations), and one area of weak conflict (i.e., the mean reversion of leverage). They finally concluded that the many shared predictions of the two theories of the trade-off theory and the pecking order theory tended to do well in their tests, however, when shared predictions were confirmed, attributing theory was unclear. Frank and Goyal (2003) also tested the pecking order theory using broad cross-section data of publicly listed US corporations over the period of 1971 to 1998. In contrast to the pecking order theory, they found that net stock issues tracked the financing deficit more closely than did net debt issues. They also suggested that while US large corporations showed some aspects of pecking order behavior, their results was robust neither to the inclusion of traditional leverage variables, nor to the analysis from the 1990s. They also insisted that financing deficit was less important in explaining net debt issues over time for US corporations of all sizes.

Moreover, Fama and French (2005) assumed that financing decisions of the US corporations would violate the predictions of the pecking order theory. Based on their arguments, they estimated that during the period from 1973 to 2002, the year-by-year equity decisions of more than half of their sample of US corporations violated the pecking order. A study by Kisgen (2006) examined to what extent credit ratings directly affect capital structure decisions. This paper found that corporations near a credit rating upgrade or downgrade issued less debt relative to equity than firms not near a change in rating. It was also reported that this behavior was not explained by traditional capital structure theories; credit rating dummy variables remained statistically significant when they were nested in empirical tests of the tradeoff and pecking order capital structure theories found in Shyam-Sunder and Myers (1999).

Further, Bharath et al. (2009) used a novel information asymmetry index based on adverse selection measures developed by the market microstructure literature, and tested whether information asymmetry was an important determinant of capital structure decisions, as suggested by the pecking order theory. They found that that information asymmetry did affect the capital structure decisions of the US corporations over the period of 1973 to 2002. Furthermore, they insisted that their evidence also explained why the pecking order theory was only partially successful in explaining all US companies' capital structure decisions. Furthermore, Leary and Roberts (2010) insisted that the pecking order theory was never able to accurately classify more than half of the observed financing decisions of the US corporations. Further, they also suggested that what little pecking order behavior could be found in the data was driven more by incentive conflicts, as opposed to information asymmetry.

The research of Manso et al. (2010) studied performance-sensitive debt (PSD), which is the class of debt obligations whose interest payments depend on the borrower's performance. 
They demonstrated that the existence of PSD obligations could not be explained by the trade-off theory, while consistent with the pecking order theory, PSD could be used as an inexpensive screening device. They also empirically found that US corporations choosing PSD loans were more likely to improve their credit ratings than corporations choosing fixed-interest loans. Finally, de Jong et al. (2011) tested the static trade-off theory against the pecking order theory for the US corporations. Their study focused on an important difference in theoretical prediction. Namely, the static trade-off theory discusses that a corporation increases leverage until it reaches its target leverage ratio, while the pecking order theory produces debt issuance until the debt capacity is reached. Their evidence indicated that generally, the pecking order theory was a better descriptor of US corporations' issue decisions than the static trade-off theory. In contrast, when they focus on repurchase decisions, their evidence suggested that the static trade-off theory was a stronger predictor of US companies' capital structure decisions.

\section{International Empirical Evidence}

This section provides the literature that offers the evidence related to the pecking order theory in the international countries other than US. We firstly document the empirical evidence from the international studies. Then following subsections supply the empirical evidence in the European countries and that in the Asia-Pacific countries. Furthermore, the final subsection introduces the evidence from the survey research.

\subsection{Empirical Evidence from the International Studies}

Regarding the international studies, first, Aggarwal and Zong (2006) examined whether a corporate internal cash flow had a positive relationship with its investment level as the pecking order theory suggests. Using comparable data of corporations in the US, the UK, Japan, and Germany, they suggested that in all four countries, investment levels were significantly positively influenced by levels of internal cash flows, indicating that corporations may operate in accordance with the pecking order theory. Second, Seifert and Gonenc (2008) studied to ascertain how well pecking order theory fitted to corporations in the US, the UK, Germany and Japan. They considered that the US and UK investors had an asymmetric information problem caused, in part, by the relatively widespread stock ownership. Namely, they suggested that in two countries, managers and insiders knew more than outside investors. They also insisted that German and Japanese investors faced information asymmetric problems due to the relatively less information flows and generally less investor rights. However, their empirical results showed little overall support for pecking order behavior for the US, UK, and German corporations while the evidence was generally favorable for Japanese corporations especially during the 1980s and early 1990s.

Third, González and González (2008) investigated the effect of bank market concentration on capital structure in 39 countries. They reported that their results for 12,049 corporations over the period of 1995 to 2004 indicated that corporate leverage increased with greater bank concentration and stronger protection of creditor rights, while decreased with stronger protection of property rights. They also suggested that weaker protection of property rights raised the agency cost of external funds, leading to the preferential use of internal funds as 
assumed in the pecking order theory. They also reported that the trade-off theory was more valid in countries with stronger protection of property rights.

\subsection{Empirical Evidence in the European Countries}

In this subsection, we supply the literature documented the European countries' empirical evidence. First, using a sample of over 5,000 European corporations, Gaud et al. (2007) searched the driving factors of capital structure policies in Europe. Controlling for dynamic patterns and national environments, they showed that the capital structure policies in European corporations could not be explained by a simple trade-off or pecking order theory. They also suggested that both corporate governance and market timing influenced on the capital structure policies in Europe. Further, they found that European corporations limited themselves to an upper bound to leverage, however, not to a lower bound. Second, using the samples of the UK small and medium size corporations, Watson and Wilson (2002) empirically tested the pecking order theory's central implication. Namely, when corporations require additional finance, they prefer to use the retained earnings over debt, and debt will be preferred over new equity issues. They insisted that their findings for the UK small and medium size corporations were consistent with the pecking order theory's predictions and they also suggested that their results indicated that, within debt types, there would be a pecking order.

Third, also for the UK corporations, Tucker and Stoja (2011) examined the impact of industry membership on the capital structure dynamics over the period from 1968 to 2006. Based on their empirical results, they suggested that whilst both pecking order theory and the trade-off theory could explain certain aspects of UK companies' capital structure policies, neither supplied a satisfactory general explanation of their real-world behaviors. More specifically, they suggested that in the short-run, old economy corporations followed the standard pecking order whilst new economy corporations preferred equity to debt when external financing was required. Fourth, using the samples of French corporations, Burlacu (2000) investigated the linkage between announcement effects and equity components for 141 French Convertible Bond (CB) issues. They insisted that it could be considered that $\mathrm{CB}$ would be a proxy for the equity component. According to their results, $\mathrm{CB}$ issue announcements derived significantly negative market responses, and they interpreted that these responses were negative market reactions to the equity component. Thus they interpreted that their results supported the implication of Myers and Majluf's (1984) model.

Fifth, de Haan and Hinloopen (2003) estimated the incremental financing decision for approximately 150 Dutch corporations for the period of 1984 to 1997 . Where they distinguished internal finance and three types of external finance: bank borrowings, bond issues, and equity issues. They first estimated a multinomial logit model to investigate several predictions of both the static trade-off theory and the pecking order theory. They next estimated all possible ordered probit models in order to determine which financing policy fitted the data best. Based on their results, Dutch corporations had unique financing preferences, namely, they preferred firstly internal financing, secondly bank loans, thirdly equity issues, and finally, bond issues. Sixth, Delcoure (2007) investigated whether capital 
structure determinants in emerging Central and Eastern European (CEE) countries followed the traditional capital structure theory. They reported that neither the trade-off, pecking order, nor agency costs theories explained the capital structure policies in CEE countries. They concluded that the factors which influenced corporate leverage decisions for CEE countries were the differences of banking systems, disparity in legal systems governing corporate operations, shareholders' and bondholders' rights protections, sophistication of stock and bond markets, and corporate governance.

Finally, using samples of 117 Irish software corporations, Hogan and Hutson (2005) examined the capital structure of new technology-based corporations. Consistent with the evidence as to funding of other small businesses, they found that internal funds were the most important source of financing in new technology-based corporations. However, they reported that in apparent contradiction to the pecking order theory, for Irish software corporations, the use of debt was rare and equity financing was the prime source of external finance. In addition, via questioning chief executive officers (CFOs) by survey research, they concluded that Irish software corporations' founders often preferred outside equity to debt.

\subsection{Empirical Evidence in the Asia-Pacific Countries}

This subsection introduces the literature offered the Asia-Pacific countries' empirical evidence. First, Voutsinas and Werner (2011) examined how financial constraints, especially fluctuations in the supply of credit, influenced on the capital structure of 1,537 publicly traded Japanese corporations. Their sample period was from 1980 to 2007 and their data set included 33,000 observations. Also, they documented that their study was motivated by Leary (2009) and Faulkender and Petersen (2006). They reported that their panel data analysis derived the empirical results that financial policy decisions of publicly listed Japanese corporations were indeed affected by monetary conditions and the supply of credit. They also found that in particular, smaller sized corporations faced financial constraints, especially during economic downturns.

Second, Suchard and Singh (2006) analyzed the Australian case. They documented that the Australian capital market had many distinct characteristics that could distinguish it from typical US and European markets. More specifically, they reported that there was a limited listed debt market where most corporations used bank debt, convertible debt was not callable and stand alone warrants were used to raise capital. Based on these differences, they examined the determinants of security choice for hybrid issuers in the Australian markets, and they suggested that their results supported the pecking order theory. Third, Chakraborty (2010) investigated Indian capital markets. In order to search the capital structure determinants of Indian corporations, they used two alternative econometrical estimation methods, namely, fully modified OLS (FMOLS) and generalized method of moments (GMM). They used a panel of 1,169 non-financial listed corporations over the period from 1995 to 2008. They reported that among the three alternative theories of capital structure, both the pecking order theory and the static trade-off theory explained Indian companies' financial decisions, and that the results obtained were robust across the estimation methods. They also reported that little evidence to support the agency cost theory were found. 
Fourth, Qian et al. (2009) studied the capital structure determinants for 650 Chinese publicly traded corporations over the period from 1999 to 2004. Although they were not always related to the pecking order theory, their main findings were as follows: First, Chinese corporations adjusted toward an equilibrium level of leverage ratio in a given year at a rather slow rate. Second, corporation size, tangibility and state shareholdings were positively related to companies' debt ratios, while profitability, non-debt tax shields, growth and volatility were negatively associated with companies' debt ratios. Third, Chinese corporations tended to adjust faster their leverage levels if they are farther away from the equilibrium debt level. Finally, Lin et al. (2008) examined the linkage between managerial optimism and corporate financing decisions by empirically testing Heaton's (2002) model. Heaton showed that, besides information asymmetry, managerial optimism could also lead to pecking order preference in financing decisions. Lin et al. (2008) tested whether pecking order preference performed better when managers were more optimistic. Using listed Taiwanese companies as their sample, they found that optimistic chief executive officers (CEOs) exhibited a stronger relation between debt issue and financing deficit, when compared with non-optimistic CEOs. They also interpreted that these findings were consistent with the predictions of Heaton's model.

\section{Evidence from the Survey Research}

This section offers the literature documented the evidence related to the pecking order theory from survey research. First, Graham and Harvey (2001) surveyed 392 CFOs in the US corporations regarding the cost of capital, capital budgeting, and capital structure. According to their survey research, corporations were concerned about financial flexibility and credit ratings when issuing debt, and earnings per share dilution and recent stock price appreciation when issuing equity. They also found some support for the pecking order and trade-off theories but little evidence that executives were concerned about asset substitution, asymmetric information, transactions costs, free cash flows, or personal taxes. Second, Brounen et al. (2006) presented the results of an international survey among 313 CFOs of capital structure choice. Their survey research offered several interesting insights on how theoretical concepts were applied by professionals in the UK, the Netherlands, Germany, and France. They reported that their results included the presence of pecking order behavior; however, their findings suggested that this behavior was not driven by asymmetric information considerations. They also found that private corporations differed in many respects from publicly listed corporations; for example, listed corporations used their stock prices for the timing of new issues.

Third, Beattie et al. (2006) reported the evidence from a comprehensive survey of corporate financing decision making in UK listed corporations. A key finding of their survey research was that corporations were heterogeneous in their capital structure policies. Namely, they reported that about half of the corporations sought to maintain a target debt level, consistent with trade-off theory, but $60 \%$ claimed to follow a financing hierarchy, consistent with the pecking order theory. They also reported that their results also indicated that cross-country institutional differences had a significant impact on corporate financing decisions. Fourth, using a firm-level survey database covering 48 countries, Beck et al. (2008) investigated how 
financial and institutional development affected financing of large and small corporations. They reported that small corporations and corporations in countries with poor institutions used less external finance, especially bank finance. Their finding also suggested that protection of property rights increased external financing of small corporations significantly more than that of large corporations, mainly due to its effect on bank finance. They further found that larger corporations more easily expanded external financing when they are constrained than small corporations. Their finding also included the suggestive evidence that the pecking order held across countries.

Finally, Vasiliou and Daskalakis (2009) provided survey information regarding the capital structure determinants in Greece and compared their findings with those of similar surveys in the US and Europe based on Graham and Harvey (2001), Bancel and Mittoo (2004), and Brounen et al. (2006). They reported that Greek corporations seemed to follow own-business policies and seemed to care more about the disadvantages of debt than exploiting its advantages. Their finding also suggested that financial distress considerations, market timing and competitiveness were important factors, whereas agency costs of equity, pecking order and the signaling theories did not seem to be applied. They finally concluded that differences in institutional characteristics did not seem to affect the way of thinking of financial managers when they decide on capital structure issues.

\section{Conclusions}

This paper has surveyed the international evidence of the capital structure issues, particularly focusing on the pecking order theory of corporate financing. As our survey demonstrates, both empirical and survey evidence are often different and contradictory. As Myers (2003) documented, the theories of capital structure are conditional, and one theory alone is not always complete; each works better in some conditions than in others. Further progress may need deeper understanding of these conditions. We would also require better theory which explains how managers conduct financing, acting as agents for shareholders.

Nevertheless, our newest international survey, which includes both empirical results and survey evidence, contributes to update the knowledge and understanding of international academic researchers and practitioners engaged in corporate finance. We consider that future works exploiting international data sets based on the rich information from this survey will be valuable. These works will lead to more worldwide conclusions, and these are our future task.

\section{Acknowledgements}

The author acknowledges the generous financial assistance of the Japan Society for the Promotion of Science. Further, I greatly appreciate the invitation of the Editors to write to this new journal, and I also thank anonymous referees for their helpful comments.

\section{References}

Aggarwal, R., \& Zong, S. (2006). The cash flow-investment relationship: International evidence of limited access to external finance. Journal of Multinational Financial Management, 16, 89-104. 
Allen, F., Bhattacharya, S., \& Rajan, R. (2008). The Contributions of Stewart Myers to the Theory and Practice of Corporate Finance. Journal of Applied Corporate Finance, 20, 8-19.

Bancel, F., \& Mittoo, U. (2004). Cross-country determinants of capital structure choice: A survey of European firms. Financial Management, 33, 103-133.

Beattie, V., Goodacre, A., \& Thomson, S. J. (2006). Corporate Financing Decisions: UK Survey Evidence. Journal of Business Finance and Accounting, 33, 1402-1434.

Beck, T., Demirgüç-Kunt, A., \& Maksimovic, V. (2008). Financing patterns around the world: Are small firms different? Journal of Financial Economics, 89, 467-487.

Bharath, S. T., Pasquariello, P., \& Wu, G. (2009). Does Asymmetric Information Drive Capital Structure Decisions? Review of Financial Studies, 22, 3211-3243.

Brennan, M., \& Kraus, A. (1987). Efficient financing under asymmetric information. Journal of Finance, 42, 1225-1243.

Brounen, D., de Jong, A., \& Koedijk, K. (2006). Capital structure policies in Europe: Survey evidence. Journal of Banking and Finance, 30, 1409-1442.

Burlacu, R. (2000). New evidence on the pecking order hypothesis: the case of French convertible bonds. Journal of Multinational Financial Management, 10, 439-459.

Cadsby, C. B., Frank, M., \& Maksimovic, V. (1990). Pooling, Separating, and Semiseparating Equilibria in Financial Markets: Some Experimental Evidence. Review of Financial Studies, 3, 315-342.

Cadsby, C. B., Frank, M., \& Maksimovic, V. (1998). Equilibrium Dominance in Experimental Financial Markets. Review of Financial Studies, 11, 189-232.

Chakraborty, I. (2010). Capital structure in an emerging stock market: The case of India. Research in International Business and Finance, 24, 295-314.

Chirinko, R. S., \& Singha, A. R. (2000). Testing static tradeoff against pecking order models of capital structure: a critical comment. Journal of Financial Economics, 58, 417-425.

Constantinides, G. M., \& Grundy, B. D. (1989). Optimal investment with stock repurchase and financing as signals. Review of Financial Studies, 2, 445-465.

de Haan, L., \& Hinloopen, J. (2003). Preference hierarchies for internal finance, bank loans, bond, and share issues: evidence for Dutch firms. Journal of Empirical Finance, 10, $661-681$.

de Jong, A., Verbeek, M., \& Verwijmeren, P. (2011). Firms' debt-equity decisions when the static tradeoff theory and the pecking order theory disagree. Journal of Banking and Finance, $35,1303-1314$.

Delcoure, N. (2007). The determinants of capital structure in transitional economies. International Review of Economics and Finance, 16, 400-415.

Dybvig, P. H., \& Zender, J. F. (1991). Capital structure and dividend irrelevance with asymmetric information. Review of Financial Studies, 4, 201-219.

Fama, E. F., \& French, K. R. (2002). Testing Trade-Off and Pecking Order Predictions about Dividends and Debt. Review of Financial Studies, 15, 1-33. 
Fama, E. F., \& French, K. R. (2005). Financing decisions: who issues stock? Journal of Financial Economics, 76, 549-582.

Faulkender, M., \& Petersen, M. A. (2006). Does the source of capital affect capital structure? Review of Financial Studies, 19, 45-79.

Frank, M. Z., \& Goyal, V. K. (2003). Testing the Pecking Order Theory of Capital Structure. Journal of Financial Economics, 67, 217-248.

Fulghieri, P., \& Lukin, D. (2001). Information production, dilution costs, and optimal security design. Journal of Financial Economics, 61, 3-42.

Garlappi, L., \& Huang, J. (2006). Are stocks desirable in tax-deferred accounts? Journal of Public Economics, 90, 2257-2283.

Gaud, P., Hoesli, M., \& Bender, A. (2007). Debt-equity choice in Europe. International Review of Financial Analysis, 16, 201-222.

González, V. M., \& González, F. (2008). Influence of bank concentration and institutions on capital structure: New international evidence. Journal of Corporate Finance, 14, 363-375.

Graham, J. R., \& Harvey, C. R. (2001). The theory and practice of corporate finance: evidence from the field. Journal of Financial Economics, 60, 187-243.

Guriev, S., \& Kvasov, D. (2009). Imperfect competition in financial markets and capital structure. Journal of Economic Behavior and Organization, 72, 131-146.

Harris, M., \& Raviv, A. (1991). The Theory of Capital Structure. Journal of Finance, 46, 297-356.

Heaton, J. (2002). Managerial optimism and corporate finance. Financial Management, 31, $33-45$.

Helwege, J., \& Liang, N. (1996). Is there a pecking order? Evidence from a panel of IPO firms. Journal of Financial Economics, 40, 429-458.

Hennessy, C. A., Livdan, D., \& Miranda, B. (2010). Repeated Signaling and Firm Dynamics. Review of Financial Studies, 23, 1981-2023.

Hogan, T., \& Hutson, E. (2005). Capital structure in new technology-based firms: Evidence from the Irish software sector. Global Finance Journal, 15, 369-387.

Jung, K., Kim, Y., \& StuIz, R. M. (1996). Timing, investment opportunities, managerial discretion, and the security issue decision. Journal of Financial Economics, 42, 159-185.

Kisgen, D. J. (2006). Credit Ratings and Capital Structure. Journal of Finance, 61, 1035-1072.

Leary, M. T. (2009). Bank loan supply, lender choice, and corporate capital structure. Journal of Finance, 64, 1143-1185.

Leary, M. T., \& Roberts, M. R. (2010). The peckingorder, debt capacity, and information asymmetry. Journal of Financial Economics, 95, 332-355.

Lee, H., \& Gentry, J. A. (1995). An Empirical Study of the Corporate Choice Among common Stock, Convertible Bonds and Straight Debt: A Cash Flow Interpretation. Quarterly Review of Economics and Finance, 35, 397-419. 
Lin, Y., Hu, S., \& Chen, M. (2008). Testing pecking order prediction from the viewpoint of managerial optimism: Some empirical evidence from Taiwan. Pacific-Basin Finance Journal, $16,160-181$.

Manso, G., Strulovici, B., \& Tchistyi, A. (2010). Performance-Sensitive Debt. Review of Financial Studies, 23, 1819-1854.

Morellec, E., \& Schürhoff, N. (2011). Corporate investment and financing under asymmetric information. Journal of Financial Economics, 99, 262-288.

Myers, S. C. (1984). The Capital Structure Puzzle. Journal of Finance, 39, 575-592.

Myers, S. C. (2003). Financing of Corporations. In G. Constantinides, M. Harris, \& R. Stulz (Eds.), Handbook of the Economics of Finance: Corporate Finance. Amsterdam, North Holland: Elsevier. pp. 215-253.

Myers, S. C. (1977). Determinants of Corporate Borrowing. Journal of Financial Economics, $5,147-175$.

Myers, S. C., \& Majluf, N. S. (1984). Corporate financing and investment decisions when firms have information that investors do not have. Journal of Financial Economics, 13, $187-221$.

Noe, T. H. (1988). Capital structure and signaling game equilibria. Review of Financial Studies, 1, 331-355.

Persons, J. C. (1994). Renegotiation and the Impossibility of Optimal Investment. Review of Financial Studies, 7, 419-449.

Qian, Y., Tian, Y., \& Wirjanto, T. S. (2009). Do Chinese publicly listed companies adjust their capital structure toward a target level? China Economic Review, 20, 662-676.

Rocheteau, G. (2011). Payments and liquidity under adverse selection. Journal of Monetary Economics, forthcoming.

Seifert, B., \& Gonenc, H. (2008). The international evidence on the pecking order hypothesis. Journal of Multinational Financial Management, 18, 244-260.

Shenoy, C., \& Koch, P. D. (1996). The firm's leverage-cash flow relationship. Journal of Empirical Finance, 2, 307-331.

Shyam-Sunder, L., \& Myers, S. C. (1999). Testing Static Tradeoff against Pecking Order Models of Capital Structure. Journal of Financial Economics, 51, 219-244.

Suchard, J., \& Singh, M. (2006). The determinants of the hybrid security issuance decision for Australian firms. Pacific-Basin Finance Journal, 14, 269-290.

Tucker, J., \& Stoja, E. (2011). Industry membership and capital structure dynamics in the UK. International Review of Financial Analysis, 20, 207-214.

Vasiliou, D., \& Daskalakis, N. (2009). Institutional characteristics and capital structure: A cross-national comparison. Global Finance Journal, 19, 286-306.

Voutsinas, K., \& Werner, R. A. (2011). Credit supply and corporate capital structure: Evidence from Japan. International Review of Financial Analysis, 20, 320-334.

Watson, R., \& Wilson, N. (2002). Small and Medium Size Enterprise Financing: A Note on 


\section{Macrothink}

Business and Economic Rese arch ISSN 2162-4860 2011, Vol. 1, No. 1: E1

Some of the Empirical Implications of a Pecking Order. Journal of Business Finance and Accounting, 29, 557-578.

\section{Copyright Disclaimer}

Copyright reserved by the author(s).

This article is an open-access article distributed under the terms and conditions of the Creative Commons Attribution license (http://creativecommons.org/licenses/by/3.0/). 